\title{
PENGEMBANGAN BUKU SAKU ELEKTRONIK BERBASIS MIND MAPPING PADA MATERI LAJU REAKSI
}

\author{
Sanjangi Ailillah ${ }^{1 *}$, Eka Junaidi ${ }^{2}$, Aliefman Hakim ${ }^{3}$, Saprizal Hadisaputra ${ }^{4}$ \\ 1234 Program Studi Pendidikan Kimia, Universitas Mataram. Jalan Majapahit No. 62 \\ Mataram, NTB83112, Indonesia. \\ * Coressponding Author. E-mail: ailillahsanjangi@gmail.com
}

\section{Received: 17 Juni 2021}

\author{
Accepted: 30 November 2021 Published: 30 November 2021 \\ doi: 10.29303/cep.v4i3.2728
}

\begin{abstract}
Absrak
Penelitian ini merupakan penelitian pengembangan (Research and Development) yang bertujuan untuk mengetahui: (1) Validtas dari buku saku elektronik berbasis mind mapping pada materi laju reaksi kelas XI MIPA yang dikembangkan. (2) Kepraktisan dari buku saku elektronik berbasis mind mapping pada materi laju rekasi kelas XI MIPA yang dikembangkan. Desain penelitian yang digunakan pada penelitian ini adalah 4D (define, design, develop, dissemination). Populasi dalam penelitian ini adalah siswa kelas XI MIPA SMAN 1 Utan dengan sampel sebanyak 20 orang secara acak yang kemudian dijadikan responden untuk uji coba terbatas terhadap produk yang dikembangkan. Hasil penelitian ini menunjukkan nilai validitas yang diperoleh menggunakan indeks Aiken adalah $\mathrm{V}=0,73$ dengan kategori valid dan menunjukkan bahwa buku saku elektronik berbasis mind mapping yang dikembangkan layak digunakan. Kepraktisan buku saku elektronik berbasis mind mapping yang dikembangkan dapat dilihat dari respon siswa dengan rata-rata kepraktisan sebesar 88,95\% dengan kategori sangat praktis dan menunjukkan bahwa buku saku elektronik berbasis mind mapping yang dikembangkan sangat praktis digunakan. Berdasarkan data tersebut dapat disimpulkan bahwa buku saku elektronik berbasis mind mapping pada materi laju reaksi kelas XI MIPA yang dikembangkan bersifat valid dan sangat praktis untuk digunakan.
\end{abstract}

Kata kunci: Pengembangan, buku saku elektronik, mind mapping, laju reaksi

\section{The Development of Electronic Pocket Book Based on Mind Mapping on Reaction Rate Topic}

\begin{abstract}
This research was a research and development study that aimed to examine: the validity and practicality of the electronic pocket book based on developed mind mapping on reaction rate topic XI MIPA class. The design of the research was $4 D$ (define, design, develop, dissemination). The population in this research were the students of SMAN 1 Utan from XII MIPA class with a random sample of 20 people was taken as the practicality respondents. The result of this research showed that the validity value obtained using the Aiken index was $V=0.73$ with a valid category and the electronic pocket book based on developed mind mapping was suitable to be applied. The practicality of electronic pocket book based on developed mind mapping could be seen from the students' responses with an average practicality of $88.95 \%$ in the highly practical category and it showed that the electronic pocket book on developed mind mapping was highly practical to be applied. Based on the data, it could be concluded that the electronic pocket book on developed mind mapping on reaction rate topic XI MIPA class was valid and highly practical to be applied.
\end{abstract}

Keywords: Develop, electronic pocket book, mind mapping, rate of reaction 


\section{Chemistry Education Practice, 4 (3), 2021 - 311}

\section{Ailillah, Junaidi, Hakim, Hadisaputra}

\section{PENDAHULUAN}

Masalah pandemi COVID-19 bukan hanya menjadi masalah krisis kesehatan dunia, tetapi juga merupakan masalah yang dihadapi dalam bidang pendidikan. Bagi dunia pendidikan, pandemi COVID-19 memberikan dampak pola pembelajaran yang luar biasa, diantaranya kegiatan pembelajaran yang semula secara langsung harus dilakukan secara daring. Langkah yang diambil pemerintah bertujuan untuk memutus penyebaran COVID-19, tanpa mengurangi hak-hak peserta didik untuk tetap belajar (Mastura, 2020). Adanya kegiatan pembelajaran online menyebabkan kurangnya interaksi langsung guru dan siswa, sehingga siswa harus memiliki media pembelajaran yang baik, mudah, dan efektif untuk membantu belajar secara mandiri.

Menurut Suryanda (2020) dengan menggunakan buku paket dapat mempercepat peserta didik untuk mencapai tujuan pembelajaran apabila ada sumber belajar lain yang digunakan oleh siswa pada materi pembelajaran tersebut. Keterbatasan jumlah buku paket siswa yang disediakan sekolah membuat siswa kesulitan dalam belajar, sedangkan kehadiran buku sebagai media pembelajaran utama yang sering digunakan siswa sangat dibutuhkan, apalagi dalam materi-materi yang dianggap sulit oleh siswa.

Salah satu materi kimia pada kelas XI yang dianggap sulit oleh siswa adalah materi laju reaksi. Menurut Sholihah (2019) mata pelajaran kimia seperti laju reaksi merupakan suatu bahasan materi dengan konsep dan perhitungan yang dapat menjadi kendala bagi siswa dalam mengikuti pembelajaran kimia. Berdasarkan hasil pengamatan melaksanakan PLP (Pengenalan Lapangan Persekolahan), siswa kesulitan dalam memahami konsep teori tumbukan dan energi aktivasi, pengaruh luas permukaan dan katalis terhadap laju reaksi, serta penentuan orde reaksi.

Kesulitan siswa disebabkan oleh rumus yang diberikan di buku relatif rumit. Buku paket yang dibagikan di sekolah menyajikan materi yang kompleks dan menggunakan bahasa yang relatif sulit dipahami siswa, sehingga siswa merasa bosan dan kurang tertarik dengan buku paket (media pembelajaran) yang tebal dan penjelasan panjang, serta tidak merujuk pada inti materi.

Berdasarkan kondisi tersebut, salah satu upaya yang dapat ditawarkan adalah membuat suatu inovasi pembelajaran berupa pengembangan buku saku elektronik berbasis mind mapping. Menurut Syahroni (2016) buku saku elektronik berbasis android dapat digunakan sebagai media yang layak untuk pembelajaran serta berfokus pada aspek kognitif. Menurut Firdaus (2019) buku saku digital diambil dari penggabungan buku saku dan buku digital yang memiliki makna buku elektronik berukuran kecil yang berisi segala informasi yang dibutuhkan si pembaca.

Buku saku yang akan dikembangkan dalam penelitian ini, dibuat lebih sederhana agar mudah dipahami dengan membuat poin-poin penting berupa mind mapping. Menurut Amin (2016) mind map merupakan sebuah model pembelajaran yang menggunakan instrumen sebagai alat bantu pemetaan isi atau materi sehingga nantinya hasil pemetaan tersebut lebih mudah dipelajari dan dianalisis. Penggunaan mind mapping dapat membantu siswa dalam menempatkan informasi ke dalam suatu sistem dan dapat mengeluarkan kembali (recall) materi saat diperlukan sebagai dasar pengetahuan.

Berdasarkan uraian dari latar belakang di atas, penelitian "Pengembangan Buku Saku Berbasis Mind Mapping Pada Materi Laju Reaksi Kelas XI MIPA" perlu dilakukan sebagai upaya membantu siswa dalam belajar dengan menggunakan buku (media pembelajaran) yang lebih praktis dan menarik.

\section{METODE}

Jenis Penelitian yang digunakan adalah jenis penelitian pengembangan (Research and Development). Produk yang dikembangkan dalam penelitian ini adalah buku saku elektronik berbasis mind mapping pada materi laju reaksi kelas XI MIPA di SMAN 1 Utan. Menurut Sugiyono (2017) metode penelitian dan pengembangan dapat didefinisikan sebagai cara ilmiah untuk meneliti, merancang, memproduksi dan untuk menguji validitas dari produk yang telah dihasilkan. Penelitian dilakukan di SMAN 1 Utan pada tahun ajaran 2020/2021. Pada bulan Februari-Maret 2021 dimulai dari tahapan persiapan. Penelitian dimulai pada bulan April 2021.

Populasi pada penelitian ini adalah siswa kelas XI MIPA SMAN 1 Utan, yang terdiri dari tiga kelas, yakni kelas XI MIPA 1, XI MIPA 2, dan XI MIPA 3 dengan jumlah 103 siswa. Sampel yang digunakan pada penelitian ini adalah sebanyak 20 orang sampel.

Model penelitian yang digunakan pada penelitian ini adalah penelitian pengembangan 4D, yang terdiri dari define (pendefisian), design (perancangan), development (pengembangan), dan dessiminate (penyebaran). Penelitian ini hanya melakukan sampai tahap development (pengembangan). Tahap keempat yaitu dessiminate (penyebaran) tidak dilakukan, 


\section{Chemistry Education Practice, 4 (3), 2021 - 312}

Ailillah, Junaidi, Hakim, Hadisaputra

karena pada penelitian ini hanya sampai pada tahap menghasil produk berupa buku saku elektronik berbasis mind mapping pada materi laju reaksi kelas XI MIPA.

Instrumen yang digunakan pada penelitian ini, yaitu: (1) lembar validasi, (2) angket respon siswa untuk mengetahui kepraktisan dari buku saku elektronik berbasis mind mapping. Lembar validasi digunakan untuk mengukur validitas dari buku sakuelektronik berbasis mind mapping pada penelitian ini. Angket respon siswa sebagai instrumen pada penelitian ini, digunakan untuk mengetahui pendapat siswa terhadap buku saku elektronik berbasis mind mapping yang dikembangkan.

Data dianalisis menggunakan analisis deskripktif. Analisis data validitas ahli menggunakan rumus yang diusulkan oleh Aiken Menurut Sapo (2020) skor yang telah diperoleh selanjutnya digunakan untuk menghitung indeks kesepakatan ahli (Rater Agreement) dengan indeks Aiken (1985) yang merupakan indeks untuk menunjukkan kesepakatan hasil penilaian para ahli tentang validitas, baik untuk butir maupun untuk perangkatnya.

$$
\mathrm{V}=\frac{\sum s}{n(c-1)}
$$

Keterangan

$\mathrm{V}=$ Indeks kesepakatan validator mengenai validitas butir

S = Skor yang ditetapkan setiap validator dikurangi skor terendah dalam kategori yang dipakai ( $\mathrm{s}=$ r-l)

$\mathrm{n}=$ Banyaknya validator

$\mathrm{c}=$ Banyaknya kategori yang dipilih validator

Nilai validitas tersebut dapat diinterpretasikan dengan menggunakan pengklasifikasian. Pengklasifikasian dapat dilihat pada tabel berikut.

Tabel 1. Kategori indeks Aiken

\begin{tabular}{cll}
\hline $\begin{array}{c}\text { Interval hasil } \\
\text { validasi }\end{array}$ & $\begin{array}{c}\text { Kriteria } \\
\text { validitas }\end{array}$ & Kategori \\
\hline $0,80<\mathrm{V} \leq 1,00$ & Sangat tinggi & Sangat valid \\
$0,60<\mathrm{V} \leq 0,80$ & Tinggi & Valid \\
$0,40<\mathrm{V} \leq 0,60$ & Cukup tinggi & Cukup valid \\
$0,20<\mathrm{V} \leq 0,40$ & Rendah & Kurang valid \\
$0,00<\mathrm{V} \leq 0,20$ & Sangat rendah & Tidak valid \\
\hline
\end{tabular}

(Sumber: Trianto, 2009)

Kepraktisan produk berupa buku saku elektronik berbasis mind mapping ini dapat dianalisis menggunakan SkalaLikert. Analisis kepraktisan dapat diukur menggunakan persamaan berikut:

$$
\mathrm{P}=\frac{f}{N} \times 100 \%
$$

Keterangan :

$\mathrm{P}=$ Nilai akhir

$\mathrm{f}=$ Perolehan skor

$\mathrm{N}=$ Skor maksimum

Rentang kriteria kepraktisan dapat dilihat pada tabel di bawah ini.

Tabel 2. Kriteria kepraktisan

\begin{tabular}{lll}
\hline No. & Nilai & Kriteria \\
\hline 1. & $80 \%<\mathrm{x} \leq 100 \%$ & Sangat praktis \\
2. & $60 \%<\mathrm{x} \leq 80 \%$ & Praktis \\
3. & $40 \%<\mathrm{x} \leq 60 \%$ & Cukup praktis \\
4. & $20 \%<\mathrm{x}<40 \%$ & Kurang praktis \\
5. & $0 \%<\mathrm{x} \leq 20 \%$ & Tidak praktis \\
\hline
\end{tabular}

(Sumber: Riduwan, 2009)

\section{HASIL DAN PEMBAHASAN}

Define

Tahapan define dilakukan beberapa tahapan, seperti menganalisis kebutuhan, menentukan tujuan pembelajaran, menentukan isi dan urutannya, dan menentukan media yang dipakai. Tahap pertama yang dilakukan pada tahapan define adalah melakukan analisis kebutuhan. Analisis kebutuhan dilakukan dengan mengamati pola pembelajaran secara langsung pada materi laju reaksi. Kegiatan pengamatan tersebut membuat peneliti mengetahui apa saja kendala yang dihadapi siswa yang ada dalam kegiatan belajar mengajar pada materi laju reaksi.

Tahapan selanjutnya yaitu menentukan tujuan pembelajaran. Tujuan pembelajaran pada materi laju reaksi disesuaikan dengan kompetensi dasar dan indikator, sehingga didapatkan isi/materi yang sesuai untuk dimuat pada buku saku elektronik berbasis mind mapping.

Tahapan terakhir yang dilakukan pada tahap define yakni menentukan media yang digunakan. Penentuan media ini memperhatikan kondisi tempat penelitian, untuk memudahkan siswa mengakses media pembelajaran berupa buku saku elektronik berbasis mind mapping maka digunakan media elektronik, dimana buku saku elektronik yang telah dikembangkan dapat diakses melalui smartphone maupun laptop.

\section{Design}

Tahapan perancangan (design) dilakukan beberapa tahap kegiatan, seperti menentukan format buku saku elektronik berbasis mind mapping serta melakukan rancangan isi dan 


\section{Chemistry Education Practice, 4 (3), 2021 - 313}

Ailillah, Junaidi, Hakim, Hadisaputra

sampul dari buku saku elektronik berbasis mind mapping.

Tahapan pertama yaitu penentuan format buku saku elektronik berbasis mind mapping. Format yang dirancang untuk buku saku elektronik berbasis mind mapping terdiri dari tiga bagian, yaitu pendahuluan, inti dan penutup. Setelah melakukan penentuan, maka didapatkan format pendahuluan yang terdiri dari halaman judul, kata pengantar dan daftar isi. Bagian isi yang terdiri dari isi materi dari laju reaksi, dan bagian penutup yang terdiri dari soal evaluasi dan daftar pustaka.

Penulisan rancangan pada buku saku elektronik berbasis mind mapping juga mengalami beberapa perubahan, sesuai dari saran dan masukan dosen pembimbing. Hasil produk buku saku elektronik berbasis mind mapping yang didapatkan pada tahap ini adalah produk buku saku elektronik berbasis mind mapping prototype 1 .

\section{Develop}

Produk berupa buku saku elektronik berbasis mind mapping yang telah dihasilkan pada tahap design (prototype 1) selanjutnya diuji kevaliditasannya. Uji validitas diuji menggunakan lembar validitas ahli yang terdiri dari beberapa aspek untuk dinilai, seperti kegrafikan, penyajian, isi/materi, kebahasaan, karakteristik dari produk yang dikembangkan (mind mapping dan kemandiriannya).

Berdasarakan hasil analisis yang telah dilakukan, produk buku saku elektronik berbasis mind mapping pada materi laju reaksi yang dikembangkan setelah dilakukan validasi oleh tiga orang validator, didapatkan nilai validitas untuk setiap aspek yang dinilai pada tabel 3 di bawah ini.

Tabel 3. Nilai kevalidan produk

\begin{tabular}{lcl}
\hline \multicolumn{1}{c}{ Aspek yang dinilai } & Nilai & \multicolumn{1}{c}{ Kategori } \\
\hline Kegrafikan & 0,81 & Sangat Valid \\
Penyajian & 0,73 & Valid \\
Isi & 0,70 & Valid \\
Kebahasaan & 0,75 & Valid \\
Mind mapping & 0,75 & Valid \\
Kemandirian & 0,72 & Valid \\
\hline
\end{tabular}

Berdasarkan tabel 3 didapatkan nilai $\mathrm{V}$ untuk aspek kegrafikan sebesar 0,81 yang yang tergolong dalam kategori sangat valid, beberapa butir yang dinilai seperti susunan/tata letak tampilan, tampilan background, kesesuaian isi, gambar dan jenjang judul, serta penggunaan warna, jenis dan variasi huruf pada produk yang dikembangkan sudah terpenuhi. Menurut Arumdyahsari (2016)kegrafikan merupakan suatu hal yang penting dalam mengembangkan suatu bahan ajar atau buku, karena untuk membaca isi dari suatu buku pembaca akan melihat terlebih dahulu sampul dna bentuk bahan ajar ataupun buku.

Aspek penyajian nilai $\mathrm{V}$ yang didapatkan sebesar 0,73 yang tergolong dalam kategori valid, butir yang dinilai seperti sistematika penyajian buku, tujuan pembelajaran, contoh soal dan daftar pustaka pada produk yang dikembangkan, berdasarkan hasil penilaian validator pada butir tujuan pembelajaran belum diuraikan tujuan apa yang akan dicapai, namun nilai kevaliditasan pada aspek penyajian termasuk dalam kategori valid. Menurut Asyhari (2016) buku teks yang baik berisi konsepkonsep yang disajikan secara menarik,sehingga sebuah buku teks pembelajaran harus memperhatikan komponen penyajian.

Aspek isi/materi nilai $\mathrm{V}$ yang didapatkan sebesar 0,70 yang tergolong dalam kategori valid, butir yang dinilai seperti kesesuaian materi dengan $\mathrm{KD}$, informasi dalam buku saku memberikan pengetahuan baru dan menumbuhkan rasa ingin tau, berdasarkan hasil penilaian validator pada butir kesesuaian KD dan pengetahuan baru masih kurang pada buku saku yang dikembangkan, namun berdasarkan hasil perhitungan aspek isi pada produk yang dikembangka termasuk dalam kategori valid. Menurut Asyhari (2016) buku teks pelajaran yang baik harus memperkatikan komponen kelayakan isi, yaitu minimal mengacu pada apa yang akan dicapai oleh siswa.

Aspek kebahasaan nilai $\mathrm{V}$ yang didapatkan sebesar 0,75 yang tergolong dalam kategori valid, butir yang dinilai seperti kalimat yang digunakan pada buku saku yang dikembangkan sederhana, bahasa yang digunakan membangkitkan rasa ingin tau, dan kesesuaian dengan KBBI sudah terpenuhi dan tergolong dalam kategori valid. Menurut Asyhari (2016) sebuah buku teks pembelajaran harus memperhatikan komponen kebahasaannya, buku teks pelajaran berisi informasi, pesan, dan pengetahuan yang dituangkan dalam bentuk tertulis yang dapat dikomunikasikan kepada pembaca.

Aspek mind mapping nilai $\mathrm{V}$ sebesar 0,75 yang tergolong dalam kategori valid, butir yang dinilai seperti tampilan mind mapping, kemudahan mind mapping dalam membantu siswa sudah terpenuhi dan termasuk dalam kategori valid. Menurut Harini (2016) mind mapping adalah peta perjalanan yang bagus bagi 


\section{Chemistry Education Practice, 4 (3), 2021 - 314}

Ailillah, Junaidi, Hakim, Hadisaputra

ingatan, dengan adanya peta tersebut memberikan kemudahan dalam mengatur fakta dan juga hasil pikiran, sehingga cara kerja alami otak dilibatkan sejak awal.

Aspek kemandirian nilai $\mathrm{V}$ yang didapatkan sebesar 0,73 yang tergolong dalam kategori valid, butir yang dinilai seperti ketuntasan produk yang dikembangkan dalam menuntun siswa belajar, dan kemudahan penggunaan produk dalam membantu siswa siswa belajar secara mandiri sudah terpenuhi dan termasuk dalam kategori valid. Nilai rata-rata yang didapatkan untuk validitas buku saku eletronik berbasis mind mapping yang dikembangkan berdasarkan enam aspek tersebut, sebesar 0,74 yang tergolong dalam kategori valid.

Saran dan masukan dari validator kemudian aplikasikan padabuku saku elektronik berbasis mind mapping dan menghasilkan produk prototype 2 untuk diujikan pada uji coba terbatas.

Langkah terakhir pada penelitian ini adalah uji kepraktisan dengan 20 orang sampel yang diambil secara acak. Berikut adalah tabel nilai kepraktisan yang didapat berdasarkan respon siswa terhadap buku saku elektronik berbasis mind mapping yang dikembagkan.

Tabel 4. Hasil respon siswa terhadap buku saku elektronik berbasis mind mapping

\begin{tabular}{lll}
\hline $\begin{array}{l}\text { Aspek } \\
\text { Penilaian }\end{array}$ & $\begin{array}{l}\text { Kepraktisan } \\
(\%)\end{array}$ & Kategori \\
\hline Kemenarikan & 89 & Sangat Praktis \\
Isi/materi & 88 & Sangat Praktis \\
Kebahasaan & 87 & Sangat Praktis \\
Kualitas teknik & 92 & Sangat Praktis \\
\hline
\end{tabular}

Berdasarkan hasil respon siswa terhadap buku saku elektronik berbasis mind mapping yang dikembangkan, nilai persentase untuk aspek kemenarikan buku saku elektronik berbasis mind mapping sebesar $89 \%$ yang tergolong dalam kategori sangat praktis, aspek kemenarikan ini dlihat dari bentuk produk yang dikembangkan yaitu berupa buku saku, dimana buku saku memiliki ukuruan yang lebih kecil dan sederhana dan dapat dilihat pada layar elektronik, menurut Syahroni (2016) buku saku elektronik adalah buku elektronik sederhana dapat dibawa kemana saja, serta memuat informasi dalam bentuk teks ataupun gambar yang dapat dilihat pada layar digital.

Aspek isi/materi persentase yang didapatkan sebesar $88 \%$ yang termasuk dalam kategori sangat praktis, isi pada buku saku elektronik dibuat lebih sederhana tanpa mengurangi isi dari materi yang dibahas, menurut Firdaus (2019) isi buku lebih jelas dan ringkas, serta isi mudah dimengerti karena bacaannya relatif sedikit.
Nilai presentase pada aspek kebahasaan didapatkan sebesar $87 \%$ yang memenuhi kriteria sangat praktis, bahasa yang dibuat pada produk juga dibuat sederhana untuk memudahkan siswa belajar secara mandiri, hal ini dikarenakan pada produk yang dikembangkan terdapat mind mapping yang memudahkan siswa untuk belajar, menurut Amin (2016) mind map merupakan sebuah model pembelajaran yang menggunakan instrumen sebagai alat bantu pemetaan isi atau materi sehingga nantinya hasil pemetaan tersebut lebih mudah dipelajari dan dianalisis. Individu dapat dibantu menggunakan mind map agar dapat menempatkan informasi kedalam suatu sistem dan dapat mengelurakan kembali (recall) saat diperlukan sebagai dasar pengetahuan.

Kepraktisan pada aspek kualitas teknik didapatkan nilai persentase sebesar 92\% yang tergolong dalam kategori sangat praktis, kualitas teknik menyangkut tentang kemudahan dalam menggunakan produk dimana produk yang dikembangkan menggunakan media elektronik dan bisa diakses dalam keadaan offline dapat menghemat biaya penggunaan, menurut Nurmala (2019) kelebihan dari buku saku digital adalah selain ukurannya yang kecil dan membuatnya mudah dibawa kemana-mana, buku saku digital tidak memerlukan ruang penyimpanan besar. Persentase nilai rata-rata yang didapatkan untuk kepraktisan buku saku eletronik berbasis mind mapping yang dikembangkan berdasarkan empat aspek tersebut, sebesar $88,95 \%$ yang tergolong dalam kategori sangat praktis.

Saran dan masukan yang didapatkan dari uji kepraktisan kemudian dijadikan acuan untuk merivisi buku saku elektronik berbasis mind mapping yang dikembangkan, sehingga didapatkan produk akhir berupa buku saku elektronik berbasis mind mapping prototype 3 .

\section{SIMPULAN}

Berdasarkan hasil dari penelitian dan pengembangan yang telah dilakukan buku saku elektronik berbasis mind mapping pada meteri laju reaksi kelas XI MIPA yang dikembangkan menggunakan meode 4D (define, design, develop, and dissimenation) berada pada kategori valid dan sangat praktis, sehingga layak digunakan untuk proses pembelajaran. 


\section{Chemistry Education Practice, 4 (3), 2021 - 315}

Ailillah, Junaidi, Hakim, Hadisaputra

\section{DAFTAR PUSTAKA}

Amin, M. (2016). Pengaruh Mind Map dan Gaya Belajar terhadap Hasil Belajar Matematika Siswa. Tadris: Jurnal Keguruan Dan Ilmu Tarbiyah, 1(1), 85-92.

Arumdyahsari, S., Hs, W., \& Susanto, G. (2016). Pengembangan bahan ajar Bahasa Indonesia bagi Penutur Asing (BIPA) tingkat madya. Jurnal Pendidikan: Teori, Penelitian, dan Pengembangan, 1(5), 828834.

Asyhari, A., \& Silvia, H. (2016). Pengembangan Media Pembelajaran Berupa Buletin dalam Bentuk Buku Saku untuk Pembelajran IPA Terpadu. Jurnal Ilmiah Pendidikan Fisika Al-Biruni, 5(1), 1-13.

Firdaus, H. A. (2019). Pengembangan Aplikasi Buku Saku Digital Berbasis AndroidSebagai Media Pembelajaran Mobile Pada Mata Pelajaran

Pemrograman Dasar Bagi Siswa Kelas X TKJ di SMKN 1 Sidayu Gresik. ITEdu: Jurnal Information Technology and Education, 3(02), 121- 138.

Harini, L. P. I., \& Oka, T. B. (2016). Penggunaan Mind Map dalam Pembuktian Matematika. Jurnal Matematika,6(1), 5667.

Mastura, M., \& Santaria, R. (2020). Dampak Pandemi COVID-19 Terhadap Proses Pengajaran Bagi Guru Dan Siswa. Jurnal Studi Guru Dan Pembelajaran,3(2), 289-295.

Nurmala, R., Izzatin, M., \& Mucti, A. (2019). Desain Pengembangan Buku Saku Digital Matematika SMP Berbasis Android Sebagai Media Pembelajaran dalam Meningkarkan Minat Belajar Siwa. Edukasia:JurnalPendidikan, 6(2), 417.

Riduwan. (2009). Belajar Mudah Penelitian untuk Guru, Karyawan, dan Peneliti Pemula. Bandung: Alfabeta.

Sapo, A., Anas, M., \& Tahang, L. (2020). Pengembangan Rencana Pelaksanaan Pembelajaran IPA Berbasis Levels of Inquiry untuk Mengembangkan Keterampilan Berpikir Kritis Peserta Didik Materi Usaha dan Pesawat Sederhana Tingkat SMP/MTs. Jurnal Penelitian Pendidikan Fisika, 5(1), 35-45.

Sholihah, A., Laksmiwati, D., \& Haris, M. (2019). Pengaruh Pembelajaran Berbasis Masalah terhadap Prestasi Belajar Kimia. Chemistry Education Practice, 2(1), 24-29.
Sugiyono. (2017). Metode Penelitian dan Pengembangan (Research and Development). Bandung :Alfabeta.

Suryanda, A., Azrai, E. P., \& Julita, A. (2020). Analisis Kebutuhan Pengembangan Buku Saku Biologi Berbasis Mind Map (BIOMAP). Jurnal Pendidikan Matematika Dan IPA, 11(1), 86-98.

Syahroni, M., Nurrochmah, S., \& Amiq, F. (2016). Pengembangan buku saku elektronik berbasis android tentang signal-signal wasit futsal untuk wasit futsal di kabupaten pasuruan. Jurnal Pendidikan Jasmani, 26(2), 304-317.

Trianto. (2009). Mendesain Model Pembelajaran Inovatif- Progresif. Jakarta: Kencana Preda Media Grup. 